\title{
An Interview Study of the Experiences of Firefighters in Regard to Psychological Contract and Stressors
}

\author{
Fazeelat Duran $^{1}$ (D) $\cdot$ Jessica Woodhams $^{1} \cdot$ Darren Bishopp $^{1}$
}

Published online: 22 February 2018

(C) The Author(s) 2018. This article is an open access publication

\begin{abstract}
As the first qualitative study of its kind, this study explored firefighters' beliefs and experiences about the psychological contract between themselves as employees and their employer, workplace stress, stress-management strategies, and their wellbeing. Eleven interviews were conducted with active firefighters from multiple fire stations in the UK. The interviews were recorded and transcribed verbatim. The transcripts were analysed using framework analysis. Five superordinate themes were identified and labelled as 'Motives', 'Mutual obligations', 'Stressors and their effects', 'Moderators', and 'Retention factors', each of which contained lower level sub-themes. Psychological contract (PC) is a useful construct to measure firefighters' perceived obligations as their responses reflected multiple facets of PC theory. The current climate of austerity measures appears to be negatively impacting on firefighters in terms of reducing numbers and placing higher task demands on those remaining. Thus, making it very difficult for the UK Fire and Rescue Service (UKFRS) to meet the perceived obligations of their employees. The findings have implications for human resource departments within UKFRS trying to manage the impact of funding cuts and they highlight the potential value of the PC as a construct around which such issues can be explored.
\end{abstract}

Keywords Firefighters $\cdot$ Psychological Contract $\cdot$ Breach $\cdot$ Stress $\cdot$ Wellbeing

Firefighting is one of the most stressful occupations with firefighters being exposed to a range of demands, which can impact upon their somatic and mental wellbeing (Beaton et al. 1997; Norwood and Rascati 2015). The stress they experience is a relevant concern for the many countries around the world that employ them and has been a topic of academic study in several countries, including Japan, the UK, Malaysia, the USA and Canada (Malek et al. 2010; Murphy et al. 2002; Saijo et al. 2008; Sommerfeld et al. 2017).

Fazeelat Duran

fxd356@bham.ac.uk

1 Frankland Building, School of Psychology, University of Birmingham, Edgbaston, Birmingham B15 2TT, UK 
In the UK in particular, industrial relations are a pressing matter within the organisational climate of UK firefighting (Brunsden and Hill 2009). Since 2010, UK Fire and Rescue Services (UKFRSs) are facing budget cuts as a result of austerity measures. In the last few years, the UK Government has reduced the funding received by the UKFRSs by $30 \%$ (CFOA 2012). At present, the austerity cuts facing UKFRSs have yet to be fully implemented, however, already there has been a reduction in the number of full-time retained and control firefighters. Specifically in England, the total number of firefighters has decreased by $3.2 \%$ in 2015 and by 14.7\% between 2005 and 2015 (Bega 2010; Gaught 2016). Greenwood (2016) has estimated that the UKFRSs could lose up to 10,000 more firefighters by 2020 . This may, in part, be due to the overall downtrend in the number of fires that are attended to on an annual basis as shown in Appendix Fig. 1, produced from the national statistics (Home Office, 2014).

Regardless of the trend in the reduction of fires, the UKFRS remains critical to public safety and it is timely to study how actions by the Government, and the implementation of these by the employer, might act as a stressor affecting the wellbeing of UK firefighters. A reduction in the number of firefighters isn't a concern limited to the UK. In the US, the total number of volunteer firefighters now exceeds the number of career firefighters and even the number of volunteers per 1000 of the population is decreasing (Haynes and Stein 2016). The present study therefore aimed to understand the experiences of firefighters working in the UK, and explores their psychological contract (PC) in the austerity climate and its impact on their stress and wellbeing.

There are number of incident-related stressors faced by Fire Service personnel that can affect their mental and physical health including time pressure, lack of sleep, fatigue, high stakes decision making, risk of injury to self or death, and exposure to other people's trauma (Bos et al. 2004; Murphy et al. 2002). The National Institute for Occupational Safety and Health (2004) has attributed an increase in deaths of firefighters to cardiac arrest and high blood pressure (Kales et al. 2009), and they are noted to suffer from weakened immune systems, musculoskeletal difficulties, and fatigue (Cohen and Herbert 1996). A common reason for leaving the Fire Service for retirement or early retirement is ill-health (Gaught 2016). Moreover, Stanley et al. (2015) have found a high risk of suicide among firefighters.

In addition to incident-related stressors, there are a host of organisational stressors that firefighters can be exposed to, which include shift patterns, overtime, excessive workload, departmental politics, harassment, poor organisational climate, poor communication, lack of training, and conflicts with co-workers and supervisors (Brough 2004; Brunsden et al. 2003; Saijo et al. 2008). These stressors can have long-term psychophysical and behavioural effects on the health of firefighters, for example, anxiety and depression (Brough 2004); burnout (Prati et al. 2011; Vaulerin et al. 2016); emotional exhaustion (Smith et al. 2003); depersonalisation (Alexander and Klien 2001); and post-traumatic stress disorder (McFarlane and Bryant 2007).

While there is evidence for a relationship between workplace stressors and poor psychological health with samples of firefighters (Brunsden et al. 2003; Prati et al. 2011; Saijo et al. 2008; Vaulerin et al. 2016), there is also the potential that such a relationship can be mediated by other positive factors. Factors such as social support, self-efficacy, coping strategies, maintaining a work/family and/or work/leisure balance, mindfulness training and resilience have all been identified as potential mediators of chronic and complex stressors in the workplace (Carpenter et al. 2015; Cowman et al. 2004; Halbesleben 2009; Khoury et al. 2013; Lambert et al. 2012; Lee et al. 2014; Regehr et al. 2003; Wong et al. 2014). The current study therefore sought to understand what incident-related and organisational stressors were being experienced by UK firefighters, as well as improve our understanding of what factors might help them buffer or manage the effects of workplace stress on their wellbeing. 
As well as potentially having a negative impact on the employee, organisational stressors are also associated with negative outcomes for the organisation itself, e.g., poor job satisfaction and subsequent staff turnover and absenteeism (Brough 2004). A comprehensive understanding of employee-employer relationships within firefighting organisations can help determine ways to tackle such organisational stressors. An area that has received less attention to date is the social exchange construct of 'psychological contract' (PC). It refers to "a person's beliefs regarding the terms and conditions of the reciprocal exchange agreement between themselves and their organisation" (Rousseau 1989, p. 123). This construct focuses on unwritten expectations, beliefs, promises or obligations between employees and employers beyond the actual written agreement (Inocencia 2012). Rousseau $(1990,1995)$ categorised the perceived obligations into transactional and relational obligations. Transactional refers to obligations that are extrinsic, that occur in a close-ended time frame, that are static and observable (e.g., pay and reward). In contrast, relational obligations are more open-ended, intrinsic, dynamic and subjective (e.g., job security) (Conway and Briner 2009; Rousseau and McLean Parks 1993). PC therefore covers a range of issues like trust, fairness, promotion, training, development and decision making (Conway and Briner 2005; Turnley and Feldman 2000). Studies of work-related stress have argued that breaches and violations of PC can make a significant contribution to the stress experienced by employees (Noblet et al. 2009). PC fulfilment has been found to predict job and life satisfaction (De Cuyper et al. 2011), resistance to change (Van de Heuvel and Schalk 2009); and the level of trust and fairness between employees and employers (Van der Vaart et al. 2015; Van der Vaart et al. 2013). Organisations that fulfill employees' PC have low work-related anxiety and depression, and job insecurity (Guest et al. 2010). The employer's fulfilment of obligations affects the employee's intentions regarding whether to resign or stay with an organisation (De Cuyper and De Witte 2006; Flood et al. 2001). In contrast, when employees' perceived obligations are broken it results in negative organisational outcomes such as increased turn over intentions, organisational distrust, and job dissatisfaction (Wayne et al. 2007).

Previous literature has linked PC breach to Social Exchange Theory (Blau 1964), which states that employees try to achieve a balance in the exchange between themselves and their employer, for example, employees work hard and in return expect to be recognised for their efforts. When the employees perceive imbalance in the fulfillment of perceived obligations, there are negative consequences. Similarly, PC breach could be linked to stress and wellbeing from a conservation of resources theory (COR) perspective. This theory states that an individual protects his/her required resources (money, health, etc.) and that perception or actual loss of such resources can trigger negative consequences (Halbesleben and Bowler 2007; Hobfoll 1989, 2001). Consistent with this theory, we argue that unmet obligations perceived as a loss of valued resources (Restubog et al. 2013) could be linked to stress and wellbeing. In high-stress jobs such as firefighting, a fulfilled PC might be one way to ameliorate the stress experienced by employees.

While there is a substantial literature on PC with employees and employers from the educational, retail, and commercial sectors, the authors could only identify three studies, which had examined this construct with firefighters (Coyle-Shapiro 2002; Coyle-Shapiro and Kessler 2003; Liao-Troth 2005). Liao-Troth sampled 85 volunteer firefighters in the US and investigated the relationship between PC formation and individual motives (such as career, values, and protection) that would imply loyalty for a longer period within the organization. No association was found between the PC type and motives, perhaps because volunteer rather than full-time, career firefighters were sampled. 
In the UK, Coyle-Shapiro (2002) and Coyle-Shapiro and Kessler (2003) applied the PC construct to two samples of public sector employees of 480 and 5709, respectively, to study the effects of perceived PC fulfilment on their attitude and behaviour. PC fulfilment was found to be a predictor of public sector employees' organisational commitment and organisational citizenship behaviour. However, only 40 and 211 of the participants were firefighters, which equates to $4 \%$ and $8 \%$ of each sample, respectively. Therefore, it is difficult to know to what extent the findings apply to firefighters, specifically.

Each of these existing studies with firefighters has used quantitative methods to measure PC. To the authors' knowledge, no previous study has utilised qualitative methods to explore how PC and the consequences of broken obligations or promises are experienced by firefighters. Therefore, the potential contribution of this study is its qualitative design and the unique sample of firefighters: this could add more detail to the otherwise dominant stream of quantitative studies among more common segments of the labour market. In the current climate of budget cuts, the outcome of the study would assist the management of UKFRS because they play an essential role in managing the PC of their firefighters. A qualitative study provides greater detail in terms of whether firefighters have different reactions to $\mathrm{PC}$ breach or are alike other professions. It is also important to conduct such a study because tests devised to measure PC (e.g., PSYCONES 2005; Rousseau 1990, 2000) have been developed with employees from the commercial, educational and retail sectors and have yet to be validated with employees from the emergency services. Therefore, the current study took a qualitative approach to address this gap in the literature.

The current study aimed to fill a gap in the literature by examining UK full-time firefighters' beliefs about mutual obligations stemming from social-cultural context. It is an uncertain time in the UK for firefighters, where taking positive actions to improve their experiences could be important. We also aimed to examine the stressors experienced by UK firefighters; this was because most studies of emergency personnel focus on the causes and effects of stress amongst police officers and paramedics, rather than firefighters (Larsson et al. 2016; Malek et al. 2010). They are, therefore, a relatively neglected group.

\section{Method}

Participants and Recruitment Participants were recruited from 11 different fire stations from within one English county. The recruitment process utilised a variety of methods including electronic and face-to-face meetings with watch commanders and firefighters. In addition, the Fire and Rescue Service Human Resource Department circulated an electronic recruitment letter to different fire stations across the county. The participants also aided recruitment by snowballing information about the study to colleagues through social networking.

In total, 11 full-time, active, front-line firefighters participated. The ethnicity of all interviewees was White, and all except one were male. Four were single and seven were married or in a relationship. Their length of operational service ranged from 1.5 years to 12.5 years. They were watch commanders $(n=2)$ and firefighters $(n=9)$.

Materials A semi-structured interview was conducted with each participant on an individual basis. At the start of the interview, demographic information was collected from the interviewee regarding their gender, ethnicity, marital status, job title, number of years worked in the Fire and Rescue Service, and number of hours worked per week. The remainder of the interview schedule consisted of open-ended questions, 
which defined areas to be explored, but which also allowed for flexibility to discuss emerging issues. With regard to $\mathrm{PC}$, the interview schedule included questions about firefighters' expectations regarding their job and employer with prompts and further questions (in some cases) related to obligations commonly mentioned in the PC literature such as development and training opportunities, and sources of support. These questions were open-ended allowing the interviewees to cover relational and/or transactional obligations. In recognition of the reciprocal nature of $\mathrm{PC}$, we asked about perceived obligations of the employee as well as of the employer, whether these were being met and, if not, why not. The flexibility of a semi-structured interview enabled us to ask follow-up questions about obligations raised by the interviewee, which did not feature in the interview schedule. In light of the association between PC fulfillment and positive outcomes as well as PC breach and violation with negative outcomes, we also asked interviewees about the positive and negative impact of their job and explored the stressors they experienced and what strategies and resources were available to them to tackle these (see Appendix Table 1).

Procedure Ethical approval for the study was obtained from the Science, Technology, Engineering and Mathematics (STEM) Research Ethics Committee. Before the commencement of the interview, the participant information sheet and consent form was provided to the participants. Their consent was obtained for the interview being audio recorded. Interviews were conducted either at the firefighter's workplace $(n=6)$ or over the telephone $(n=5)$. The mean interview length was 51 min (range: 42-56). There were no differences between the face-to-face and telephone interviews in relation to length of interview. Participants were given a $£ 20$ Love-to-Shop voucher on completion of the interview. Due to the topic of the interview, each participant was given the contact details of their occupational psychologist at work so that they could seek help, if needed. Participants were given two weeks post-interview to withdraw from the study. Once this time had passed the audio files were transcribed verbatim (replacing names with pseudonyms) and deleted.

Data Analysis Strategy Framework analysis (Gale et al. 2013; Ritchie and Lewis 2003; Ritchie and Spencer 1994) was chosen as the method of analysis since it is a systematic approach to analysis but also allows for changes to be made to the coding framework during the analytical process. Further, themes can be constructed at multiple levels. Themes are developed from the data and not a-priori. QSR Nvivo10 was used to manage the data while ensuring the analyst could still view the original material. Each respondent was allocated a row while sub-headings were organised into separate columns. Each transcript was analysed by coding the data into base units of meaning and creating free codes. These free codes were further categorised into logical themes. The generated themes for each participant were incorporated across participants to produce a list of high order categorised themes capturing shared experiences of the participants. The authors scrutinised the relationships and interactions between the themes in the chart to explain the beliefs and experiences of the firefighters sampled (Ritchie and Lewis 2003; Ritchie et al. 2013).

\section{Results and Discussion}

Five main themes were identified and were labelled 'Motives', 'Mutual obligations', 'Stressors and their effects', 'Moderators', 'Retention factors' (see Appendix Table 2). Each of these themes 
served as an umbrella theme for high-order categories. Further, these high-order themes consisted of lower-order categories and then base units of meaning. How these levels were arranged can be seen in Appendix Table 3. Moreover, how often each lower-order category and each base unit was referred to in the interviews and by interviewee is included in Appendix Table 3.

\section{Theme 1: Motives}

This theme encapsulated each of the participants' reasons for joining the Fire and Rescue Service. Within it, there were six sub-themes. 'Life time aspiration' accounted for more than two-thirds of all responses.

It was my passion to join the Fire Service from my childhood because it is an exciting job. I never thought of any other job really (Female, Firefighter 1).

The other reasons for joining the Fire Service included firefighting not being a typical job with typical hours (i.e., 'not a 9-5 job') and it having 'better career opportunities' than other jobs.

I wanted to do something that was different from the routine. By routine I mean $9-5$ jobs and there would be not a single day that is the same. (Male, Firefighter 7).

I opted for the Fire Service really; when I wanted a change...This profession provides a better career in comparison to other job structures (Male, Watch Commander 10).

Further, approximately half of the interviewees referred to the UKFRS having a generous pension scheme in comparison to other professions as a reason of joining. These officers would have joined UKFRSs prior to the implementation of financial cuts.

I chose to be a firefighter because I want to have a better living standard when I retire (Male, Watch Commander 10).

Interviewees also commented that a reason for joining was that 'not everyone can be a firefighter', which suggests the job has a special status associated with it, which gives them a feeling of pride and achievement.

I always wanted to purse this job, as it is very difficult to get into this job. (Male, Firefighter 3).

...because not everyone can get into this job easily, just like the army (Male, Watch Commander, 10).

Moreover, there was one participant who joined because of 'family tradition' i.e., his relatives were part of the Fire and Rescue Service and he grew up hearing fire-fighting stories.

My uncle was a firefighter and hearing his stories developed my interest to join this profession. It took me quite a long time to get into this job, as I wanted to join the Fire Service when I was 15 years old (Male, Watch Commander 8).

From the above, it was clear that motives for joining the Fire and Rescue Service would likely be associated with PC breach because some of the employees had joined with the perceived obligations of having better pension schemes, as compared to other professions. However, in the current climate of austerity cuts in the UK, and with the Government having brought in changes to firefighters' pension schemes in 2011 (CFOA 2012), it is likely that such perceptions are difficult for the Fire and Rescue Service, as the employer, to satisfy. Therefore, the cuts act as an external force 
triggering PC breach by the Fire and Rescue Service meaning the organisation can no longer fulfil its perceived obligations (Thompson and Bunderson 2001).

\section{Theme 2: Mutual Obligations}

This theme captured firefighters' perceptions of what the perceived obligations were of their employers ('employer obligations') and their beliefs of what their employers would expect of them ('employee obligations') (see Appendix Table 2). There were eight employer obligations that could be further categorised into relational and transactional obligations (Bunderson 2001; Rousseau 1990, 2000), and five employee obligations towards their employer, which were further categorised into the obligations of 'loyalty', and 'looking after property'.

\section{Employer Obligations}

In terms of transactional obligations, more than half of the firefighters perceived to be provided with a safe working environment by the employer, which was related to the employer providing appropriate and sufficient equipment. In addition, they spoke about the need for the employer to provide the right equipment to allow them to perform their duties with professionalism. Moreover, two of the participants spoke about financial rewards. Specifically, they talked about their belief that they would receive their pay on time and that they would be provided with a good pension scheme.

We want to be paid at the end of the day, as we need money for our living. We need a good pension scheme as well (Male, Watch Commander 10)

In addition, firefighters spoke about relational obligations (Rousseau 1990, 2000): three of the interviewees expected there to be parity in how themselves and their colleagues were treated. They talked about the stress, demands and responsibility associated with the job and that they accepted these providing they received financial security now and in the future. Cuts in the budgets of the Fire Service meant that the frontline firefighters we sampled were concerned about their job security.

I want to be treated fairly by my employer as the rest of the employees are treated. My bosses and supervisors should keep a check on whether we are treated fairly... (Male, Firefighter 4).

I expect to have a secure job when we are facing budget cuts. I want quite a secure job in terms of how long I will be protected from redundancy (Male, Firefighter 8).

Four of them referred to beliefs that their employer respect them and understand their position, as they were once at a similar stage of career.

They should realise that once they were also a firefighter. They [seniors] should respect us (Male, Firefighter 6).

Further, three firefighters expected that their employer would provide them with opportunities for advancement and growth, or training to develop into a competent firefighter, so that they are up-to-date in their job role. It was felt that this would enable them to tackle difficult situations in a professional manner. 
I want to have good training in order to deal with serious incidents... So, to develop into a competent firefighter, I need more training. This will assist me to grow in my role by being a fully competent firefighter (Male, Firefighter 5).

Three of them mentioned that they want to be provided with assistance when they are struggling with a task.

Sometimes, I want them to help me, when I am struggling with something. By something' I mean anything that is related to performing the duty with excellence (Male, Firefighter 11).

Three-quarters of the interviewees perceived that, most of the time, employers met their perceived obligations by, for example, providing training. They also mentioned that they were treated the same way as other employees within the organisation. A point they were concerned about, however, was the skills of higher management within their organisation.

I am unhappy with the selection of our senior leaders. The reason is you [high ranking officials] are selecting the people on the basis of practical skills no matter how goofy their management skills are (Male, Firefighter 3).

\section{Employee Obligations}

In terms of 'employee obligations', $90 \%$ of the interviewees felt that they fulfilled their employer's perceived promises by being 'loyal' (Bunderson 2001; Herriot et al. 1997) to the organisation, i.e., protecting the core values of the Fire and Rescue Service (being punctual, maintaining competencies, being a good team player, and performing duties with loyalty to the Fire Service). Moreover, the employers were perceived to have an expectation of their employees that equipment would be cared for (Herriot et al. 1997) and that the station would be kept clean and tidy.

My employers just want me to promote and preserve the core values of the Fire Service. These core values are definitely to perform well when a certain task is given. All the firefighters have to keep the stations clean and tidy and maintain unity within our team (Male, Firefighter 11).

One-third of the firefighters perceived their employers' obligations of them to have changed from the time they started in the job. This is consistent with previous literature (Conway and Briner 2009; De Meuse et al. 2001; Robinson et al. 1994), which suggests that the PC changes with time. However, the firefighters interviewed seemed to suggest that this wasn't a positive change and that they were now overwhelmed by the different duties required of them.

The way we do the job has changed a lot these days. It's much like we not only have to attend the incidents but also educate children. There is so much to do rather than dealing with the fire calls (Male, Watch Commander, 10).

PCs can be classified as relational or transactional (Rousseau and Tijoriwala 1998; Rousseau 2000). As noted above, employer obligations reported by our participants represent both transactional and relational elements because they refer to monetary and non-monetary exchanges within an open-ended agreement (Rousseau 1990). However, the obligations referred to by the majority of interviewees are relational because they are implicit and subjective with no clear time frame (Conway and Briner 2009). This is most likely because the firefighters sampled were all full-time (career) firefighters as opposed to part-time or volunteers, whose PCs are more transactional in 
nature. Furthermore, a few interviewees perceived a decrease in the relational component of their PC with their employer over time, in terms of reduced levels of respect, and a reduced commitment to the organisation (much alike De Meuse et al. 2001).

In terms of how the experiences of our interviewees mapped onto aspects of PC measured by existing tests, the obligations mentioned by the firefighters, such as receiving a good rate of pay, having job security, being treated fairly by the employers, and being provided with opportunities for advancement and personal growth, are similar to how employer obligations are measured in PSYCONES (2005) and Bunderson's (2001) measure of PC. These measures were developed with employees from the commercial, retail, educational and health care sectors, therefore these findings suggest that firefighters perceive similar obligations from their employers as employees in other sectors.

\section{PC Breach}

PC breach refers to when employees perceived their obligations to be unfulfilled. Within the interviews, there was some evidence that firefighters perceived a breach to their PC with their employer (Morrison and Robinson 1997). However, rather than the firefighters referring to the Fire and Rescue Service having breached the contract, their actual employer, they instead referred to the Government as the cause of the breach. So, while the employees were largely happy with their employer (the Fire and Rescue Service), three-quarters of the interviewees were unhappy with the Government, who they perceived to be the cause of the current industrial action.

\section{...Firefighters might be happy with their employers but they are not happy and satisfied with the Government. This is leading to massive strikes.... (Male, Firefighter 7).}

Within the interviews, having to "do more" was often spoken about alongside comments regarding the "financial strains" being experienced by the Fire and Rescue Service. This suggests that the increased number of tasks facing the firefighters might also stem from the reduction in their numbers (i.e., fewer personnel having to do more with less). Other quotes from the interviewees implied a general sense of feeling underresourced with the implication being that numbers could reduce further as people left the Service. This seemed to implicate a breach in the PC from the employees' perspective:

In previous years, the number of firefighters is going down. There are fewer fire engines... we have a lot of financial strains these days. If these continue, we are further going to go down in numbers (Male, Watch Commander 10).

As noted above, several of the firefighters referred to the "good pension scheme" as a reason for joining the Service and that receiving a good pension was an obligation they perceived their employer to fulfil. However, approximately $80 \%$ of the firefighters referred in negative terms to the UK Government making changes to the pension scheme within the Fire Service during their interviews:

The Government is not right by bringing change in the pension scheme (Male, Firefighter 6).

Further suggestions of breaches to their PCs lay in comments which implied they did not feel recompensed sufficiently for the challenging job they undertook, and that they were not being 
given sufficient resource to perform their job adequately (i.e., insufficient staffing and inadequate equipment).

It's because we work hard, giving our best, therefore we should be paid for it (Male, Watch Commander 8).

They (the Government) want to save money by having cuts in our budget...hmmm because of this; we have lots of financial strains and few firefighters, today. There are also fewer fire engines (Male, Firefighter 6).

The public needs to be aware of what the Government is doing with the firefighters (Male, Watch Commander 8).

As a public service, the Fire Service extends the traditional model of a PC between employer-employees since, while firefighters have an immediate employer (the Fire Service), they are also employed by the Government (Dick 2006). Further, while they have obligations to their employer, these extend to providing a service to the public. The public can have their own expectations of firefighters and the Fire Service, which may or may not be met. The quotes from the firefighters we sampled imply that firefighters are aware of this and so wish the public to be aware of the difficult circumstances in which they are operating should they not be meeting the public's expectations.

\section{Theme 3: Stressors and their Effects}

There were a number of stressors cited by the firefighters we interviewed; family/personal, organisational (circumstances within the organisation that cause stress, such as high workload, etc.), incident-related (stressors resulting from attending an incident at work), and government stressors. These stressors were identified as having a negative impact on the physical and psychological wellbeing of the firefighters in the current organisational climate of UKFRSs (see Appendix Table 3). The primary source of stress as perceived by the firefighters was referred to as 'the Government':

They (the Government) are causing stress by messing with our finances, messing with our pensions, messing with our retirement wages (Male, Watch Commander 8).

Another type of stressor faced by the interviewees was a personal stressor related to 'family problems'. More than half of the employees reported having insufficient time for family, holidays and festivals. One interviewee spoke about being unable to find any leisure time for him/herself ('personal stressor') and several talked about the difficulties of maintaining a good balance between work, home and social life. This seemed particularly relevant to participants who were in a relationship or had a family. In contrast, the employees who were not in a relationship or who were single were more satisfied in terms of their work-life balance. These findings resonate with Conway and Briner (2009) and Millward (2006) who found that events such as marriage and parenthood influence or change an employee's perceived obligations from their employer.

I am unable to make up for holidays and festivals due to my job commitments. I have no time for a social life, honestly. At times, it gets difficult for me to have a balance between my work and home (Male, Firefighter 9). 
One-quarter of the firefighters reported 'incident-related' stressors such as dealing with fires, false alarms, dealing with members of the public on the scene, and being distracted from their work by members of the public's interference. Furthermore, it was distressing for these employees when, at times, they were unable to help people involved in the incident. It seemed that incident-related stressors were not linked to PC breach.

It gets really difficult to deal with the public as they come up with their cameras and make videos. Even though, when they are asked to move back politely, they never listen to you. They think it's like we are not doing anything serious or it's not a serious job, but it is really distracting and disturbing (Male, Firefighter 5).

Sometimes you deal with nasty incidents and nasty people so it gets stressful (Male, Firefighter 4).

The firefighters interviewed reported facing 'organisational stressors', namely large amounts of paperwork, team conflicts, shift patterns (four days on and four days off), and difficulties with time management. An additional organisational stressor reported by the interviewees was a reduction in numbers of firefighters - too few firefighters puts pressure on the remaining staff to fulfil the duties required of them. This is consistent with existing literature (Gaught 2016) with one implication being that in future there might be further reductions in the number of firefighters.

The industrial action will make terms and conditions more difficult. Already we are dropping in numbers and our job is important in order to protect the community. I find this stressful... (Male, Firefighter, 11).

It was evident from the quotations that, unlike incident-related stressors, personal, government and organisational stressors were linked to PC breach that might subsequently have a negative impact on the firefighters' wellbeing.

\section{Effects of Stressors}

As a consequence of these incident-related, organisational and personal stressors, the employees reported experiencing 'physical distress' including being tired and run-down. Lack of sleep/poor sleep was a common consequence of organisational stressors (i.e., shift patterns).

When I come from the night shift it gets difficult for me to get rest (Male, Firefighter, 4). Sometimes, I am a bit tired when I am unable to manage work life and social life and shift pattern. I run down to a point that I do not have rest and this affects my sleeping pattern as well. I don't get enough sleep. (Male, Watch Commander 10).

The shift pattern being a stressor is consistent with some previous research where it was attributed to causing physical distress (Bos et al. 2004; Murphy et al. 2002). In contrast, Litchfield and Hinckley (2016) didn't find such a relationship but found that a different shift pattern (of two days and two nights on and four days off) was associated with a better work-life balance amongst firefighters.

Incident-related stressors were more often associated with muscular discomfort and pain, injuries and falling sick. A few of the interviewees reported experiencing 'psychological distress', namely mild anxiety and depression, due to personal/family stressors, in particular having no time for themselves or family. For two interviewees, their intimate relationship with a partner had also ended because they were unable to balance work and home life. Firefighters also mentioned 
emotional or physical exhaustion resulting from the demands of the job. In addition, Halbesleben (2009) found that emotional exhaustion could result from work-family conflict.

I found myself exhausted by push and pull. In this environment, I was suffering from mild anxiety and stress affecting my sleep, life, and mood. I was unable to manage work life and home life. I was unable to give time when my kids wanted me (Male, Firefighter 4).

Our findings accord with previous conclusions about firefighters facing organisational stressors, family stressors (Brunsden et al. 2014), and incident-related stressors (Brown et al. 2002). In addition, our sample referred to stressors attributed to the Government. This was considered as an external stressor acting on the Fire Service as an employer preventing fulfillment of employees' perceived obligations, such as having a good pension, and sufficient workforce and resources.

\section{Theme 4: Moderators}

Several factors were cited by the interviewees as being utilised to manage stress in the job. These were grouped under 'moderators' (alike Dean et al. 2003; Regher et al. 2003). 'Social support' was quoted by all the firefighters as the best method to buffer the effects of stress. This accords with previous literature that has cited social support as a buffer for high stress levels (Haslam and Mallon 2003; Young et al. 2014). Interviewees reported that there were sufficient resources within the organisation to offer social support when needed (i.e., 'organisational support'). These sources included the occupational health department, their watch colleagues, the Watch Commander and the Union. Our findings suggested that all the employees felt they had adequate social support irrespective of their length of the experience, whereas Regher et al. (2003) found newly recruited firefighters received more support than experienced firefighters. Moreover, alike Young et al.'s (2014) findings, the interviewees that had less experience particularly mentioned seeking social support from more experienced members of the watch as a way of managing distress.

There is also an occupational health department, who deal with our stressors. Everyone supports each other at watch level. I also belong to the union and my union supports me in case of dealing with stress (Male, Firefighter 11).

Mixed reports were given of drawing on external sources of social support, such as from families, friends and relatives, to buffer the effects of stress. A few interviewees mentioned that they would prefer not to talk to their family because of the distressing nature of incidents they work with and to avoid their families worrying about them at work. Similar findings were reported by Menendez et al. (2006) and Yoo and Matsui (2012).

I have got enough support from my family and friends, but I can't share with them everything as they can be taken aback with this role, I don't want them feel bad and concerned about me when I am at work (Male, Firefighter 11).

However, there were a few firefighters who did seek support from friends and family, although they again seemed to indicate a preference for talking with work colleagues, perhaps due to their immediate availability after an incident, as alluded to below:

I talk to my partner and friends and I also talk to my colleagues. They are the people we interact with immediately after the incident (Male, Watch Commander 10). 
Similarly, Brunsden et al. (2014) found that firefighters prefer to seek support from colleagues because they spend most of their time at the fire stations and their colleagues are, therefore, the people they encounter after attending a fire incident. In addition, family members who were part of the firefighting family provided an extension of such support:

I think I am quite lucky that I have family and friends who support me. I come from a firefighter family... (Male, Firefighter 3).

A range of approaches were used to manage stressors, beyond drawing on social support. A minority of interviewees reported using 'avoidance' strategies such as diverting attention from a source of stress by engaging in another activity (e.g., going to the cinema), or focusing on resolving the issue while at the incident itself. One interviewee spoke about the use of alcohol by colleagues to cope. Brown et al. (2002) investigated the coping strategies of Irish firefighters and found that they resorted to avoidance strategies during period of distress.

A few of the interviewees seemed to use 'mindfulness' (Walach et al. 2007) as a coping strategy: they reported not becoming easily stressed or they reported accepting that stressors were part of the job. Mindfulness has been reported to be a beneficial strategy in overcoming anxiety and depression, and for improving relationships (Khoury et al. 2013). Other studies have reported the beneficial effects of mindfulness techniques for coping with stress with US military service personnel (Jha et al. 2017), and emergency room nurses (Westphal et al. 2015).

\section{Theme 5: Retention Factors}

Besides interviewees finding being a firefighter a challenging job for the range of reasons outlined above and some of them reporting a breach to their PC, the employees enjoyed being part of the Fire Service. The 'retention factors' that had meant they hadn't left the Fire Service were; job diversity, helping people involved in incidents, educating children, and colleagues becoming part of their social network. Moreover, employees experienced positive 'personal changes' within themselves. They reported that they had developed more awareness of their surroundings with time, in terms of being more aware of the causes of fires and other incidents and therefore they take steps to protect themselves and their families. They have become more accomplished at dealing with emergency situations potentially due to their coping strategies having changed over time. Moreover, one of them mentioned becoming more vigilant. Whether this is a positive change is unclear since being hypervigilant can inhibit relaxation (Sommerfeld et al. 2017).

When I am in public surroundings, I always keep myself aware of any emergency incident that might take place. I think what actions I need to take and how I need to deal with the situation, hmmm... how to save people (Female, Firefighter 1).

Four firefighters felt they had developed personally to become more confident, competent, mature and responsible. They described how they had learned to control their nerves and that they had become stronger emotionally.

I have built up my confidence. By confidence I mean my social skills are improved a lot when I am within a social gathering (Male, Firefighter 11).

I consider I am more responsible person. I think I probably know how to deal if something goes wrong (Male, Firefighter 5). 
A few of the interviewees reported that they had now learned how to balance work-life demands and that that had come with experience.

It is very convenient for me to balance between family and work life now after these many years. I do not have any family issues. I know how to draw a line between work and home (Male, Watch Commander 8).

\section{General Discussion}

The present study aimed to understand the experiences of firefighters working in the UK, and explores their PC in a climate of austerity and its impact on their stress and wellbeing. When asked about their expectations of their employer and the obligations that their employer should meet, evidence of both transactional and relational obligations was forthcoming (Rousseau 1990, 1995). The sorts of obligations cited by our participants overlapped with those cited by employees in other sectors that have formed the basis for the development of measures of PC (e.g., Bunderson 2001; Herriot et al. 1997; PSYCONES 2005; Rousseau 1990, 2000), for example, receiving a good rate of pay, having job security, being treated fairly by the employers, and being provided with opportunities for advancement and personal growth (Guest et al. 2010). This suggests that quantitative measures of PC, such as these listed, should be applicable for use with firefighters.

The climate of austerity cuts in the UK and its impact on the UKFRS was thought to make this a particularly relevant time at which to consider the importance of the PC with firefighters due to its theoretical links with stress, mental wellbeing and workforce behaviour (e.g., retention). From the interviews, it was apparent that firefighters were experiencing breaches to their PC regarding being suitably recompensed for the difficult job they do, and having insufficient resources (physical and human) to conduct their role to the best of their ability. Reactions to perceived breaches of PC differ depending on the type of PC (Robinson et al. 1994). Employees with a relational contract are at greater risk of severe PC breach (Grimmer and Oddy 2007). Moreover, if an employee continues to work within the organisation after a perceived breach of PC has occurred, the contract is likely to become more transactional in nature (Atkinson 2007; Pate et al. 2003). Therefore, in the current scenario, where the UKFRS is facing austerity cuts, and as a result of these cuts the employers are unable to fulfil the perceived obligations of their employees (e.g., providing a good pension schemes), it is likely that firefighters will develop a more transactional PC (short-term and focused on monetary exchanges) (Lester et al. 2007). As per Blau's (1964) Social Exchange Theory, employees try to achieve a balance in the exchange between themselves and their employer, for example, expecting suitable recompense (current and future) for the demanding and dangerous job they do. When there is an imbalance, which looks unlikely to be redressed, negative consequences such as resignation can result. Other reactions to broken promises or obligations can include employees taking action that breaches their obligations to their employer (Zhao et al. 2007), such as participating in industrial action. It was evident that $\mathrm{PC}$ breach was associated with stressors and psychological distress. This is in line with COR theory (Hobfoll 1989) suggesting that PC breach results in stress and impacts wellbeing when the employees' valuable resources (i.e., perceived employer obligations) are not sustained. 
The findings from this study suggest that the PC of an employee is not just shaped by their employer or organisation, but also by the Government, media, and public. Further, the perceived obligations of the employer can change depending on the broader context of the employee, such as becoming a parent or getting married.

The firefighters sampled in this paper varied in terms of their length of service and this provided the opportunity to compare themes that emerged in the interviews of experienced firefighters compared to newer recruits. Length of service appeared to be associated with the type of obligations cited by the firefighters as well as their responses to other areas of the interview. In terms of PC, the obligation cited by firefighters with less than three years' experience related to advancement and growth, as compared to those with more years of service who focused more on training and development, and relational obligations. This difference could be explained by new recruits being more focused on becoming a 'competent firefighter'. With regards to stressors, newer recruits discussed incident-related stressors more than experienced firefighters (e.g., difficulties dealing with the public on the scene and being distracted by public interference). Also, it was these interviewees who reported the distress experienced when they were unable to help someone at an incident. Their focus on becoming a competent firefighter might be in response to experiencing the stress associated with such situations which they assume will pass with growing experience and competence. These findings coupled with the newer recruits explaining how they have developed over time indicate the value of a future study that investigates changes in the PC, stressors and coping over time with participants from the Fire and Rescue Service.

\section{Limitations}

There were some limitations in this study that need to be acknowledged. The sample cannot be considered representative of all U.K. firefighters because the sample size was small and limited to one geographical area of the U.K. Further, the study focused on the employees' perspectives only (a unilateral approach to PC) therefore a future study should also examine the perspective of the employer and/or the occupational health department.

\section{Implications}

This paper makes a theoretical contribution to the literature by providing support for the theory of PC with an understudied population, suggesting that existing measures of PC should be suitable for use with firefighters. It also highlights how, within some sectors, the notion of one employer is too simplistic with employees perceiving themselves as having obligations to others beyond their immediate employer (i.e., to the public), and others beyond their immediate employer having obligations to them (e.g., the Government).

Austerity cuts are not something that the firefighters' direct employer (the UKFRS) has control over, therefore, it's important to consider what the employer could still do to address breaches in PC. The employer could, for example, foster closeness between employees and ensure opportunities for career development and recognition (Ebadan and Winstanley 1997; Nadin and Williams 2011; Robinson and Morrison 2000). Watch Commanders could hold confidential one-to-one meetings with individual firefighters to provide a "safe" environment in which perceived breaches can be discussed (Lester et al. 2007). Moreover, senior management should avoid creating any further distance between themselves and their employees because this would give 
the impression that the employer is less inclined about the relationship with their employees (Coyle-Shapiro and Prazefall 2008). It is positive that so many of the interviewees viewed their direct employer (the UKFRS) in a positive light. Further, some organisational stressors could be ameliorated by acting to minimise role overload and improving employees' perceptions of career progression (Gakovic and Tetrick 2003; Xavier and Jepsen 2015).

From our interviews, it is clear that the firefighters experienced a range of stressors within and outside of work, which negatively impact on their physical and mental wellbeing. Therefore, strategies should be implemented by the UKFRS to resolve the issues that cause negative outcomes. For example, for incident-related stressors, the UKFRSs can ensure there are sufficient debriefing opportunities following a difficult incident, especially with newer recruits. Another important consideration is what, if any, action can be taken to assist firefighters in creating a better work-home life balance. This might include exploring different shift patterns that could be adopted. Since some stressors are intrinsic to the job, training in mindfulness, which appears to be having success in associated professions (Jha et al. 2017; Westphal et al. 2015), is another intervention that could be trialed and evaluated.

\section{Conclusion}

The aim of the current study was to address a gap in the literature on PC theory by adopting qualitative methods to explore its relevance to the firefighting profession. PC was found to be a valid construct in understanding firefighters' obligations as their responses reflected multiple facets of PC theory. The current climate of austerity measures in the UK appears to be negatively impacting on firefighters in terms of reducing numbers and placing even higher task demands on those employees remaining. This makes it very difficult for the UKFRS to meet the perceived obligations of their employees providing evidence of PC breach. A range of coping strategies were reported by the firefighters interviewed. The findings have implications for human resource departments within UKFRS trying to manage the impact of funding cuts and they highlight the potential value of the PC as a construct around which such issues can be explored.

Funding This study was self-funded.

\section{Compliance with Ethical Standards}

Ethical Approval Ethical approval for this study was granted from the University of Birmingham's Science, Technology, Engineering and Mathematics (STEM) Ethics Committee and the Fire and Rescue Service. All procedures performed in this study involving human participants were in accordance with the ethical standards of the institution and with the 1964 Helsinki declaration and its later amendments or comparable ethical standards.

Informed Consent Informed consent was obtained from all the participants in this study.

Conflict of Interest All the authors declare that they have no conflict of interest. 


\section{Appendix}

Table 1 PC dimensions and relevant interview questions

\begin{tabular}{|c|c|}
\hline PC Dimensions & Interview Questions \\
\hline $\begin{array}{l}\text { Reciprocal exchange between themselves } \\
\text { and their employer }\end{array}$ & $\begin{array}{l}\text { What are/were your perceived obligations when you joined the } \\
\text { Fire Service? } \\
\text { Have these changed in any way? Do you feel that your } \\
\text { employer has any perceived obligations from you? } \\
\text { Are these expectations/obligations realistic? }\end{array}$ \\
\hline PC Fulfilment/Breach/Violation & $\begin{array}{l}\text { Do you feel that your employer has fulfilled their obligations } \\
\text { to you? In what way? } \\
\text { Does your employer help you in managing the stressors you } \\
\text { mention?* } \\
\text { Does your employer provide you with support? If yes, what } \\
\text { sort of support? If no, why do you think this is?* } \\
\text { How happy/satisfied are you with your work in the Fire Service? } \\
\text { Are their particular aspects that are more/less satisfying than } \\
\text { others?** }\end{array}$ \\
\hline
\end{tabular}

*Relevant to PC Fulfilment if "support" was referred to as a perceived obligation

**Identified areas of PC fulfilment/breach

Table 2 Key themes and their definitions $(n=11)$

\begin{tabular}{ll}
\hline Key themes & Definition \\
\hline $\begin{array}{l}\text { Motives } \\
\text { Mutual obligations }\end{array}$ & $\begin{array}{c}\text { The different reasons given by interviewees for joining the Fire Service. } \\
\text { The perceived obligations that firefighters have of their employers and } \\
\text { their perceptions of their employer's obligations of them. } \\
\text { Different types of stressors referred to by the interviewees, namely } \\
\text { organisational, personal/family, incident-related and government stressors. } \\
\text { The reported effects of these stressors on the interviewees' wellbeing. } \\
\text { External and internal support used to buffer the effects of stressors. } \\
\text { Different coping strategies implemented by each individual. } \\
\text { The aspects of the job and changes over time that assist in the retention } \\
\text { of employees. }\end{array}$ \\
\hline
\end{tabular}


Table 3 High-order, low-order categories and base units of meaning by participants $(\mathrm{N}=11)$

\begin{tabular}{ll} 
High-order categories $\quad$ Low-order categories $\quad$ Base units of meaning \\
\hline
\end{tabular}

Motives $(n=11 ; 21)$

Employer obligations

Transactional obligations $(n=8 ; 31)$

Relational obligations $(n=11 ; 41)$

Employee obligations

PC breach $(n=9 ; 71)$

Types of stressors

Its affects

Moderators
Loyalty $(n=11 ; 47)$

Look after the property $(n=11 ; 11)$

Organisational stressors $(n=11 ; 27)$

Government stressors $(n=11 ; 33)$

Personal/family stressors $(n=7 ; 18)$

Incident-related stressors $(n=5 ; 30)$

Psychological distress $(n=5 ; 19)$

Physical distress $(n=6 ; 14)$

Social support $(n=11 ; 57)$
Life time aspiration $(n=1 ; 5)$

Not a $9-5$ job $(n=2 ; 3)$

Not everyone can be a firefighter $(n=2 ; 2)$

Better career opportunities $(n=7 ; 7)$

Good pension schemes $(n=7 ; 3)$

Family tradition $(n=1 ; 1)$

Financial rewards $(n=2 ; 5)$

Safe working environment $(n=8 ; 11)$

Appropriate equipment $(n=8 ; 15)$

Job security $(n=6 ; 6)$

Respect $(n=4 ; 7)$

Treated fairly $(n=3 ; 5)$

Provide assistance if I am struggling $(n=3 ; 4)$

Training and development /advance and growth $(n=3 ; 19)$

Being punctual and professional $(n=9 ; 9)$

To perform duties with trust and fairness $(n=11 ; 11)$

Good teamwork $(n=10 ; 15)$

Maintain competencies $(n=9 ; 12)$

To keep station clean and tidy $(n=11 ; 11)$

Do more $(n=9 ; 15)$

Financial strain $(n=8 ; 10)$

Under resourced $(n=9 ; 15)$

Changes to pension scheme $(n=7 ; 14)$

Government a major cause of problem $(n=9 ; 17)$

Meeting set targets $(n=2 ; 4)$

Amount of paper work $(n=5 ; 6)$

Shift pattern $(n=4 ; 5)$

Reduction in firefighter numbers $(n=8 ; 8)$

Time management at work $(n=1 ; 2)$

Dealing with people in station $(n=2 ; 2)$

Change in pension scheme $(n=9 ; 14)$

Financial budget cuts $(n=8 ; 11)$

Massive strikes $(n=7 ; 8)$

No sufficient time for family $(n=7 ; 9)$

No leisure time for one's own self $(n=1 ; 2)$

Having balance between work and life $(n=7 ; 7)$

Buildings on fire $(n=2 ; 6)$

Unable to help people in incidents $(n=2 ; 9)$

Serious incidents $(n=5 ; 6)$

Dealing with public on scene $(n=3 ; 4)$

Distracted by people's interference $(n=2 ; 2)$

False alarms $(n=2 ; 3)$

Mild anxiety $(n=3 ; 6)$

No 'me' time $(n=3 ; 3)$

More depressed $(n=5 ; 6)$

Unable to manage social, work and home life $(n=2 ; 4)$

Sore and tired muscles $(n=1 ; 2)$

Remain sick a lot $(n=2 ; 2)$

Lots of injuries $(n=1 ; 3)$

Lack of sleep $(n=6 ; 7)$

Talk to friends, family $(n=7 ; 16)$

Talk to partner $(n=7 ; 8)$ 
Table 3 (continued)

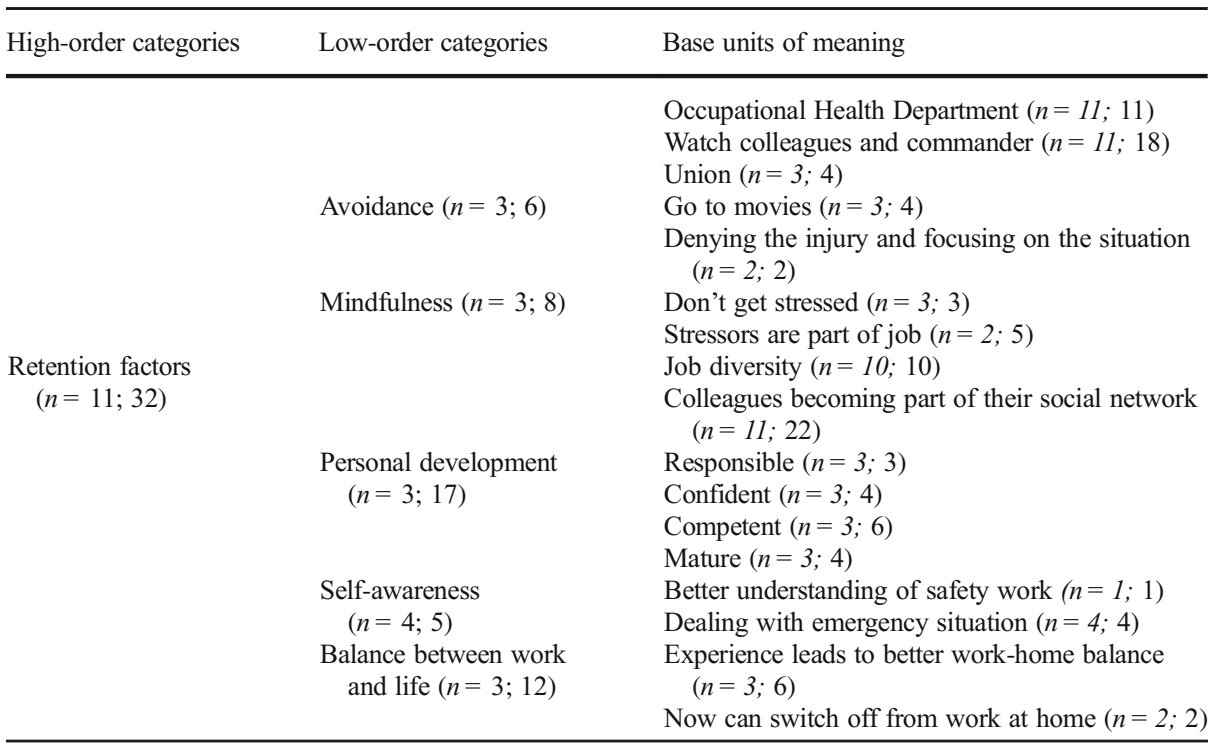

$(n=)=$ the number of interviewees citing the theme/base unit and this is followed by the number of times the theme or base unit was cited overall

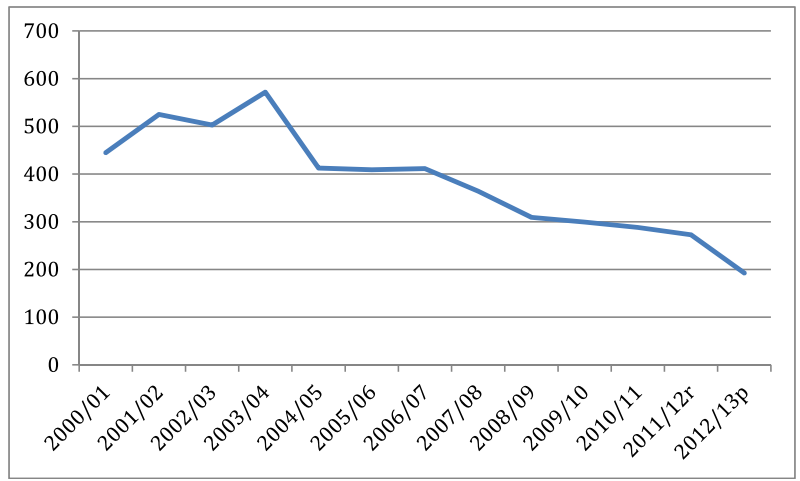

Fig. 1 The downward trend in fires occurring in UKFRS between 2000 and 2013 based on statistics reported in national statistics (2014) 
Open Access This article is distributed under the terms of the Creative Commons Attribution 4.0 International License (http://creativecommons.org/licenses/by/4.0/), which permits unrestricted use, distribution, and reproduction in any medium, provided you give appropriate credit to the original author(s) and the source, provide a link to the Creative Commons license, and indicate if changes were made.

\section{References}

Alexander, D. A., \& Klien, S. (2001). Ambulance personnel and critical incidents. Impact of Accident and Emergency Work on Mental Health and Emotional Well-being, 178(1), 76-81. https://doi.org/10.1192 /bjp.178.1.76.

Atkinson, C. (2007). Trust and the psychological contract. Employee Relations, 29(3), 227-246. https://doi. org/10.1108/01425450710741720

Beaton, R. D., Murphy, S. A., Pike, K. C., \& Corneil, W. (1997). Social support and network conflict in firefighters and paramedics. Western Journal of Nursing Research, 19(3), 297-313. https://doi.org/10.1177 /019394599701900303

Bega, D. (2010). Fire and rescue service: operational statistics bulletin for England 2009-10. Retrieved from https://www.gov.uk/government/uploads/system/uploads/attachment_data/file/6770/1723518.pdf.

Blau, P. (1964). Exchange and power in social life. New York: Wiley.

Bos, J., Mol, E., Visser, B., \& Frings-Dresen, M. (2004). Risk of health complaints and disabilities among Dutch firefighters. International Archives of Occupational and Environmental Health, 77(6), 373-382. https://oi. org/10.1007/s00420-004-0537-y

Brough, P. (2004). Comparing the influence of traumatic and organizational stressors on the psychological health of police, fire, and ambulance officers. International Journal of Stress Management, 11(3), 227-244. https://doi.org/10.1037/1072-5245.11.3.227

Brown, J., Mulhern, G., \& Joseph, S. A. (2002). Incident-related stressors, locus of control, coping, and psychological distress among firefighters in Northern Ireland. Journal of Traumatic Stress, 15(2), 161168. https://doi.org/10.1023/A:1014816309959

Brunsden, V., \& Hill, R. (2009). Firefighters' experience of strike: An interpretative phenomenological analysis case study. Irish Journal of Psychology, 30(1-2), 99-115. https://doi.org/10.1080/03033910.2009.10446301

Brunsden, V., Woodward, L., \& Regel, S. (2003). Occupational stress and posttraumatic reactions in fire-fighters and control room staff. Fire Safety, Technology and Management, 8(3), 11-14.

Brunsden, V., Hill, R., \& Maguire, K. (2014). Putting fire \& rescue service stress management into context: a UK informed perspective. International Fire Service Journal of Leadership and Management, 7, 27-39.

Bunderson, J. (2001). How work ideologies shape the psychological contracts of professional employees: Doctor's responses to perceived breach. Journal of Organizational Behavior, 22(7), 717-741. https://oi. org/10.1002/job.112

Carpenter, G. C., Carpenter, T. P., Kimbrel, N. A., Flynn, E. J., Pennington, M., Cammarata, C., Zimering, R. T., \& Kamholz, B. (2015). Social support, stress, and suicidal ideation in professional firefighters. American Journal of Health Behavior, 39(2), 191-196. https://doi.org/10.5993/AJHB.39.2.5

CFOA (2012). Fighting fires or firefighting: the impact of austerity on English fire and rescue services. Retrieved from http://www.cfoa.org.uk/13852.

Cohen, S., \& Herbert, T. B. (1996). Health Psychology: Psychological factors and physical disease from the perspective of human psychoneuroimmunology. Annual Review of Psychology, 47(1), 113-142. https://doi. org/10.1146/annurev.psych.47.1.113

Conway, N., \& Briner, R. B. (2005). Understanding psychological contracts at work. A critical evaluation of theory and research. Oxford: Oxford University Press. https://doi.org/10.1093/acprof:oso/9780199280643.001.0001

Conway, N., \& Briner, R. (2009). Fifty years of psychological contract research: What do we know and what are the main challenges. In G. P. Hodgkinson \& J. K. Ford (Eds.), International review of industrial and organizational psychology (Vol. 24, pp. 71-130). Chichester: Wiley.

Cowman, S. E., Ferrari, J. B., \& Liao-Troth, M. (2004). Mediating effects of social support on firefighters sense of community and perceptions of care. Journal of Community Psychology, 32(2), 121-126. https://doi. org/10.1002/jcop.10089

Coyle-Shapiro, J. A. M. (2002). A psychological contract perspective on organizational citizenship behavior. Journal of Organizational Behavior, 23(8), 927-946. https://doi.org/10.1002/job.173

Coyle-Shapiro, J. A. M., \& Kessler, I. (2003). The employment relationship in the U.K. public sector. A psychological contract perspective. Journal of Public Administration Research and Theory, 13(2), 213230. https://doi.org/10.1093/jopart/mug018 
Coyle-Shapiro, J. A. M., \& Prazefall, M. (2008). Psychological contracts. In C. L. Cooper \& J. Barning (Eds.), Handbook of organizational behaviour (pp. 17-34). London: SAGE Publications.

De Cuyper, N., \& De Witte, H. (2006). The impact of job insecurity and contract type on attitudes, well-being and behavioural reports: a psychological contract perspective. Journal of Occupational and Organizational Psychology, 79, 395-409. https://doi.org/10.1348/096317905X53660.

De Cuyper, N., Van der Heijden, B. I. J. M., \& De Witte, H. (2011). Associations between perceived employability, employee wellbeing, and its contribution of organizational success: A matter of psychological contracts? The International Journal of Human Resource Management, 22(7), 1486-1503. https://doi. org/10.1080/09585192.2011.561962

De Meuse, P. K., Bergmann, T. J., \& Lester, S. W. (2001). An investigation of the relational component of the psychological contract across time, generation and employment status. Journal of Managerial Issues, 13(1), $102-118$.

Dean, P. G., Gow, K. M., \& Shakespeare-Finch, J. E. (2003). Counting the cost: Psychological distress in career and auxiliary firefighters. Australasian Journal of Disaster and Trauma Studies, 1, 1-13.

Dick, P. (2006). The psychological contract and the transition from full to part-time police work. Journal of Organizational Behavior, 27(1), 37-58. https://doi.org/10.1002/job.366

Ebadan, G., \& Winstanley, D. (1997). Downsizing, delayering and careers - the survivor's perspective. Human Resource Managment Journal, 7(1), 79-91. https://doi.org/10.1111/j.1748-8583.1997.tb00276.x

Flood, P. C., Turner, T., Ramamoorthy, N. \& Pearson J. (2001). Causes and consequences of psychological contracts among knowledge workers in the high technology and financial services industries. International Journal of Human Resource Management, 12(7), 1151-1165.

Gakovic, A., \& Tetrick, L. E. (2003). Psychological contract breach as a source of strain for employees. Journal of Business and Psychology, 18(2), 235-246. https://doi.org/10.1023/A:1027301232116

Gale, K. N., Heath, G., Cameron, E., Rashid, S., \& Redwood, S. (2013). Using the framework method for the analysis of qualitative data in multi-disciplinary health research. BMC Med Research Methods, 13(1), 117. https://doi.org/10.1186/1471-2288-13-117

Gaught, P. (2016). Fire and rescue operational statistics bulletin for England: 2015-2016. Retrieved from https://www.gov.uk/government/uploads/system/uploads/attachment data/file/563118/fire-rescueoperational-statistics-201516-hosb1216.pdf.

Greenwood, M. (2016). Why are the Government not protecting firefighters? Retrieved from https://www.fbu. org.uk/blog/why-are-government-not-protecting-firefighters.

Grimmer, M., \& Oddy, M. (2007). Violation of the psychological contract: The mediating effect of relational versus transactional beliefs. Australian Journal of Management, 32(1), 153-174. https://doi.org/10.1177 /031289620703200109

Guest, D., Isaksson, K., \& Witte, D. (2010). Employment contracts and psychological contracts among European workers. Oxford: Oxford University Press. https://doi.org/10.1093/acprof:oso/9780199542697.001.0001

Halbesleben, J. R. B. (2009). The role of work-family conflict and social support. International Journal of Workplace Health Management, 2(2), 115-130. https://doi.org/10.1108/17538350910970200

Halbesleben, J. R. B., \& Bowler, W. M. (2007). Emotional exhaustion and job performance: The mediating role of motivation. Journal of Applied Psychology, 92(1), 93-106. https://doi.org/10.1037/0021-9010.92.1.93

Haslam, C., \& Mallon, K. (2003). A preliminary investigation of post-traumatic stress symptoms among firefighters. Work and Stress, 17(3), 277-285. https://doi.org/10.1080/02678370310001625649

Haynes, H., \& Stein, G. P. (2016). NFPA'S: U.S. fire department profile. Retrieved from http://www.nfpa. org/news-and-research/fire-statistics-and-reports/fire-statistics/the-fire-service/administration/us-firedepartment-profile.

Herriot, P., Manning, W. E. G., \& Kidd, J. M. (1997). The content of the psychological contract. British Journal of Management, 8(2), 151-162. https://doi.org/10.1111/1467-8551.0047

Hobfoll, S. E. (1989). Conservation of resources: A new attempt at conceptualizing stress. American Psychologist, 44(3), 513-524. https://doi.org/10.1037/0003-066X.44.3.513

Hobfoll, S. E. (2001). The influence of culture, community, and the nested-self in the stress process: Advancing conservation of resources theory. Applied Psychology, 50(3), 337-421. https://doi.org/10.1111/14640597.00062

Home Office (2014). Fire Statistics: Great Britain April 2012 to March 2013. Retrieved from https://www.gov. $\mathrm{uk} /$ government/collections/fire-statistics-great-britain.

Inocencia, M. M. L. (2012). The importance of psychological contracts in human resource management within the new global economy. In J.-E. de Susana, F.-S. Jose Antonio, M.-M. Encarnacion, \& V.-C. Jorge (Eds.), Human resource Management in the Digital Economy: Creating synergy between competency models and information (pp. 96-124). IGI Global: Hershey. 
Jha, A. P., Morrison, A. B., Parker, S. C., \& Stanley, E. A. (2017). Practice is protective: Mindfulness training promotes cognitive resilience in high-stress cohorts. Mindfulness, 8(1), 46-58. https://doi.org/10.1007 /s12671-015-0465-9

Kales, S. N., Tsismenakis, A. J., Zhang, C., \& Soteriades, E. S. (2009). Blood pressure in firefighters, police officers, and other emergency responders. American Journal of Hypertension, 22(1), 11-20. https://oi. org/10.1038/ajh.2008.296

Khoury, L. T., Fortin, G., Masse, M., Therien, P., Bouchard, V., Chapleau, M. A., Paquin, K., \& Hofmann, S. G. (2013). Mindfulness-based therapy: A comprehensive meta-analysis. Clinical Psychology Review, 33(6), 763-771. https://doi.org/10.1016/j.cpr.2013.05.005

Lambert, J. E., Benight, C. C., Harrison, E., \& Cieslak, R. (2012). The firefighter coping self-efficacy scale: Measure development and validation. Anxiety, Stress, and Coping, 25(1), 79-91. https://doi.org/10.1080 /10615806.2011.567328

Larsson, G., Berglund, A. K., \& Ohlsson, A. (2016). Daily hassles, their antecedents and outcomes among professional first responders: A systematic literature review. Scandinavian Journal of Psychology, 57(4), 359-367. https://doi.org/10.1111/sjop.12303

Lee, J. S., Ahn,Y. S. Jeong, K. S., \& Choi, K. S. (2014). Resilience buffers the impact of traumatic events on the development of PTSD symptoms in firefighters. Journal of Affective Disorders, 162, 128-133, doi: https://doi.org/10.1016/j.jad.2014.02.031.

Lester, S. W., Kickul, J. R., \& Bergmann, T. J. (2007). Managing employee perceptions of the psychological contract over time: The role of employer social accounts and contract fulfillment. Journal of Organizational Behavior, 28(2), 191-208. https://doi.org/10.1002/job.410

Liao-Troth, M. A. (2005). Are they here for the long haul? The effects of functional motives and personality factors on the psychological contracts of volunteers. Nonprofit and Voluntary Sector Quarterly, 34(4), 510530. https://doi.org/10.1177/0899764005279513

Litchfield, I., \& Hinckley, P. (2016). Factors influencing improved attendance in the UK fire service. Occupational Medicine, 66(9), 731-736. https://doi.org/10.1093/occmed/kqw156

Malek, M. D. A., Mearns, K., \& Flin, R. (2010). Stress and psychological well-being in UK and Malaysian fire fighters. Cross Cultural Management-an International Journal, 17(1), 50-61. https://doi.org/10.1108 $/ 13527601011016907$

McFarlane, A. C., \& Bryant, R. A. (2007). Post-traumatic stress disorder in occupational settings: Anticipating and managing the risk. Occupational Medicine, 57(6), 404 410. https://doi.org/10.1093/occmed/kqm070

Menendez, A. M., Molloy, J., \& Magaldi, M. C. (2006). Health responses of new York City firefighter spouses and their families post-September 11, 2001 terrorist attacks. Issues in Mental Health Nursing, 27(8), 905917. https://doi.org/10.1080/01612840600842642

Millward, L. J. (2006). The transition to motherhood in an organizational context: An interpretative phenomenological analysis. Journal of Occupational and Organizational Psychology, 79(3), 315-333. https://doi. org/10.1348/096317906X110322

Morrison, E. W., \& Robinson, S. L. (1997). When employees feel betrayed: A model of how psychological contract violation develops. The Academy of Management Review, 22(1), 226-256.

Murphy, S. A., Bond, G. E., Beaton, R. D., Murphy, J., \& Johnson, L. C. (2002). Lifestyle practices and occupational stressors, as predictors of health outcomes in urban firefighters. International Journal of Stress Management, 9(4), 311-327. https://doi.org/10.1023/A:1020171100398

Nadin, S. J., \& Williams, C. C. (2011). Psychological contract violation beyond an employees' perspective: The perspective of employers. Employee Relations, 34(2), 110-125. https://doi.org/10.1108/01425451211191841

Noblet, A. J., Rodwell, J. J., \& Allisey, A. F. (2009). Police stress: The role of the psychological contract and perceptions of fairness. Policing-an Internatnal Journal of Police Strategies \& Management, 32(4), 613630. https://doi.org/10.1108/13639510911000731

Norwood, P. J. \& Rascati, J. (2015). Suicide is a reality in the fire service. Retrieved from http://www. fireengineering.com/articles/2015/12/fire-service-suicide.html.

Pate, J., Martin, G., \& McGoldrick, J. (2003). The impact of psychological contract violation on employee attitudes and behaviour. Employee Relations, 25(6), 557-573. https://doi.org/10.1108/01425450310501306

Prati, G., Pietrantoni, L., \& Cicognani, E. (2011). Coping strategies and collective efficacy as mediators between stress appraisal and quality of life among rescue workers. International Journal of Stress Management, 18(2), 181-195. https://doi.org/10.1037/a0021298

PSYCONES (2005). Retrieved from www.uv.es 1 psycon.

Regher, C., Hill, J., Knott, T., \& Sault, B. (2003). Social support, self-efficacy and trauma in new recruits and experienced firefighters. Stress and Health, 19(4), 189-193. https://doi.org/10.1002/smi.974

Restubog, S. L. D., Zagenczyk, T. J., Bordia, P., \& Tang, R. L. (2013). When employees behave badly: The roles of contract importance and workplace familism in predicting negative reactions to psychological contract breach. Journal of Applied Social Psychology, 43(3), 673-686. 
Ritchie, J., \& Lewis, J. (2003). Qualitative research practice. London: SAGE.

Ritchie, J., \& Spencer, L. (1994). Qualitative data analysis for applied policy research. In A. Bryman \& R. G. Burgess (Eds.), Analysing qualitative data (pp. 173-194). London: Routledge. https://doi.org/10.4324 /9780203413081_chapter_9

Ritchie, J., Lewis, J., Nicholls, C. M., \& Ormston, R. (2013). Qualitative research practice. London: SAGE.

Robinson, S. L., \& Morrison, E. W. (2000). The development of psychological contract breach and violation: A longitudinal study. Journal of Organizational Behavior, 21(5), 525-546. https://doi.org/10.1002/1099-1379 (200008)21:5<525::AID-JOB40>3.0.CO;2-T

Robinson, S. L., Kraatz, M. S., \& Rousseau, D. M. (1994). Changing obligations and the psychological contract: A longitudinal study. Academy of Management Journal, 37(1), 137-153. https://doi.org/10.2307/256773

Rousseau, D. M. (1989). Psychological and implied contracts in organizations. Employee Responsibilities and Rights Journal, 2(2), 121-139. https://doi.org/10.1007/BF01384942

Rousseau, D. M. (1990). New hire perceptions of their own and their employer's obligations: A study of psychological contracts. Journal of Organizational Behavior, 11(5), 389-400. https://doi.org/10.1002 /job.4030110506

Rousseau, D. M. (1995). Psychological contracts in organizations: Understanding written and unwritten agreements. Thousand Oaks: Sage Publications.

Rousseau, D. M. (2000). Psychological contract inventory: Technical report. Pittsburgh: Carneige Mellon University.

Rousseau, D. M., \& McLean Parks, J. (1993). The contracts of individuals and organizations. Research in Organizational Behavior, 15, 1-43.

Rousseau, D. M., \& Tijoriwala, S. A. (1998). Assessing psychological contracts: Issues, alternatives and measures. Journal of Organizational Behavior, 19 (spec issue), 679-695.

Saijo, Y., Ueno, T., \& Hashimoto, Y. (2008). Twenty-four-hour shift work, depressive symptoms, and job dissatisfaction among Japanese firefighters. [article]. American Journal of Industrial Medicine, 51(5), 380-391. https://doi.org/10.1002/ajim.20571

Smith, C. S., Folkard, S., \& Fuller, J. A. (2003). Shiftwork and working hours. In J. C. Quick \& L. E. Tetrick (Eds), Handbook of occupational Health Psychology (pp. 163-184). Washington, DC: American Psychological Association. https://doi.org/10.1037/10474-008.

Sommerfeld, A., Wagner, S. L., Harder, H. G., \& Schmidt, G. (2017). Behavioral health and firefighers: An intervention and interviews with Canadian firefighters. Journal of Loss and Trauma., 22(4), 307-324. https://doi.org/10.1080/15325024.2017.1284515

Stanley, I. H., Hom, M. A., Hagan, C. R., \& Joiner, T. E. (2015). Career prevalence and correlates of suicidal thoughts and behaviors among firefighters. Journal of Affective Disorders, 187, 163-171. https://doi. org/10.1016/j.jad.2015.08.007

The National Institute for Occupational Safety and Health. (2004). Fire Captain Suffers Sudden Cardiac Death during a Live-Fire Training Exercise-North Carolina. Retrieved from https://www.cdc. gov/niosh/fire/reports/face200327.html.

Turnley, W. H., \& Feldman, D. C. (2000). Re-examining the effects of psychological contract violations: Unmet expectations and job dissatisfaction as mediators. Journal of Organizational Behavior, 21(1), 25-40. https://doi.org/10.1002/(SICI)1099-1379(200002)21:1<25::AID-JOB2>3.0.CO;2-Z

Van de Heuvel, S., \& Schalk, R. (2009). The relationship between fulfillment $\mathrm{f}$ the psychological contract and resistance to change during organizational transformations. Social Science Information, 48(2), $283-313$. https://doi.org/10.1177/0539018409102415

Van der Vaart, L., Linde, B., \& Cockeran, M. (2013). The state of the psychological contract and employees' intention to leave: The mediating role of employee well-being. South Africa Journal of Psychology, 43(3), 356-369. https://doi.org/10.1177/0081246313494154

Van der Vaart, L., Linde, B., De Beer, L., \& Cockeran, M. (2015). Employee wellbeing, intention to leave and perceived employability: A psychological contract approach. SAJEMS NS, 18(1), 32-44. https://doi. org/10.4102/sajems.v18i1.746

Vaulerin, F., Arripe-Longueville, D.'., Emile, M., \& Colson, S. S. (2016). Physical exercise and burnout facets predict injuries in a population-based sample of French career firefighters. Applied Ergonomics, 54, 131135. https://doi.org/10.1016/j.apergo.2015.12.007

Walach, H., Nord, E., Zier, C., Dietz-Waschowski, B., Kersig, S., \& Schupbach, H. (2007). Mindfulness-based stress reduction as a method for personnel development: A pilot evaluation. International Journal of Stress Management, 14(2), 188-198. https://doi.org/10.1037/10725245.14.2.188

Wayne, Z. H., Glibkowski, S. J., \& Bravo, B. C. (2007). The impact of psychological contract breach on workrelated outcomes: A meta-analysis. Personnel Psychology, 60(3), 647-680. 
Westphal, M., Bingisser, M. B., Feng, T., Wall, M., Blakley, E., Bissinger, R., \& Klein, B. (2015). Protective benefits of mindfulness in emergency room personnel. Journal of Affective Disorders, 125, 79-85.

Wong, J. Y., Lin, J.-H., Liu, S. H., \& Wan, T.-H. (2014). Fireman's job stress: Integrating work/non-work conflict with job demand-control-support model. Revue européenne de psychologie appliquée, 64(2), 83-91. https://doi.org/10.1016/j.erap.2013.12.002

Xavier, I. M., \& Jepsen, D. M. (2015). The impact of specific job stressors on psychological contract breach and violation. Human Factors and Ergonomics in Manufacturing \& Service Industries, 25(5), 534-547. https://doi.org/10.1002/hfm.20567

Yoo, S., \& Matsui, Y. (2012). The influence of attitide of inhibiting spousal disclosure about stress oin th emental health of firefighters. Japanese Journal of Psychology, 83(5), 440-449. https://doi.org/10.4992/jjpsy.83.440

Young, P. M., Partington, S., Wetherell, M. A., Gibson, A. S. C., \& Partington, E. (2014). Stressors and coping strategies of UK firefighters during on-duty incidents. Stress and Health, 30(5), 366-376. https://doi. org/10.1002/smi.261

Zhao, H., Wayne, S. J., Glibkowski, B. C., \& Bravo, J. (2007). The impact of psychological contract breach on work-related outcomes: A meta-analysis. Personnel Psychology, 60(3), 647-680. https://doi.org/10.1111 jj.1744-6570.2007.00087.x 